\title{
Using the first European Breeding Bird Atlas for science and perspectives for the new Atlas
}

\section{Herrando, Sergi}

2019

Herrando , S, Keller , V , Bauer, H-G, Brotons , L, Eaton, M , Kalyakin , M , Voltzit , O , Lehikoinen, A , Milanesi , P , Noble , D , Ramirez , I, Vorisek , P \& Foppen , R 2019 , ' Using the first European Breeding Bird Atlas for science and perspectives for the new Atlas ' , Bird Study , vol. 66 , no. 2 , pp. 149-158 . https://doi.org/10.1080/00063657.2019.1618242

http://hdl.handle.net/10138/312708

https://doi.org/10.1080/00063657.2019.1618242

unspecified

acceptedVersion

Downloaded from Helda, University of Helsinki institutional repository.

This is an electronic reprint of the original article.

This reprint may differ from the original in pagination and typographic detail.

Please cite the original version. 


\section{Using the first European Breeding Bird Atlas for science and}

2 perspectives for the new Atlas

3 SERGI HERRANDO ${ }^{1,2}$, VERENA KELLER ${ }^{1,3}$, HANS-GÜNTHER BAUER $^{1,4}$, LLUÍS

4 BROTONS ${ }^{1,2,5,6}$, MARK EATON $^{1,7}$, MIKHAIL KALYAKIN $^{1,8}$, OLGA VOLTZIT $^{8}$, ALEKSI

5 LEHIKOINEN ${ }^{1,9}$, PIETRO MILANESI $^{1,3}$, DAVID NOBLE $^{1,10}$, IVÁN RAMÍREZ ${ }^{1,11}$ PETR

6 VOŘíŠEK ${ }^{1,12}$ \& RUUD FOPPEN ${ }^{1,13,14}$

71 European Bird Census Council, PO Box 6521, 6503 GA Nijmegen, The Netherlands.

82 Catalan Ornithological Institute. Natural History Museum of Barcelona. PI. Leonardo da Vinci

9 4-5. 08019 Barcelona, Spain.

103 Swiss Ornithological Institute. Seerose 1. $\mathrm{CH}-6204$ Sempach, Switzerland.

114 Max-Planck-Institut für Ornithologie, Vogelwarte Radolfzell, Am Obstberg 1, 78315 Radolfzell

12 Germany.

135 InForest Jru (CTFC-CREAF), Crta. Antiga St Llorenç de Morunys km 2, 25280, Solsona,

14 Spain.

156 CSIC, Cerdanyola del Vallès, Spain.

167 The RSPB Centre for Conservation Science, RSPB, Sirius House, 1 Amethyst Road,

17 Newcastle Business Park, Newcastle-upon-Tyne, United Kingdom.

188 Zoological Museum of Lomonosov Moscow State University, Bolshaya Nikitskaya Str., 2,

19 Moscow, 125009, Russia.

209 The Helsinki Lab of Ornithology, Finnish Museum of Natural History, University of Helsinki,

21 Finland.

2210 British Trust for Ornithology, The Nunnery, Thetford, Norfolk IP24 2PU, UK.

2311 BirdLife International, David Attenborough Building, Pembroke Street, Cambridge, CB2 3QZ, 24 UK. 

Netherlands.

14 Department of Animal Ecology and Ecophysiology, Institute for Water and Wetland Research, Radboud University, 6500, Nijmegen, The Netherlands.

30

SHORT TITLE: The European Bird Atlas and science

32

KEYWORDS: bird species ranges, European Bird Census Council, Western Palearctic, bibliographic research.

35 
Capsule The first EBCC Atlas of European Breeding Birds (EBBA1) has been widely used in scientific publications.

Aims To quantify how scientific publications have used data from EBBA1, what the topics of these studies have been, and to identify key aspects in which the Second European Breeding Bird Atlas (EBBA2) will provide new opportunities for basic and applied science.

Methods We searched for "EBCC Atlas of European Breeding Birds" in Google

Scholar to find papers published in scientific journals that cited EBBA1. We analysed the contents of a random selection of 100 papers citing this atlas. We described the way these papers used EBBA1.

Results EBBA1 has been cited in 3150 scientific publications, and can be regarded as a fundamental reference for studies about birds in Europe. EBBA1 was extensively used as a key reference for the studied bird species. A substantial number of papers re-analysed EBBA1 data to derive new information on species distribution, ecological traits and population sizes. Distribution and ecology were the most frequent topics of studies referring to EBBA1, but this source of information was employed in a very diverse range of studies. In this context, climate change, impact of agriculture and habitat loss were, by order, the most frequently studied environmental pressures. Constraints in EBBA1 such as the poor coverage in the East of Europe, the lack of information on distribution change and the coarse resolution were identified as issues limiting the use of EBBA1 for some purposes.

Conclusions This study demonstrates the scientific value of European-wide breeding bird atlases. EBBA2, with its almost complete coverage across Europe, the incorporation of changes in distribution between the two atlases and the inclusion of 
modelled maps at a resolution of $10 \times 10 \mathrm{~km}$ will certainly become a key data source and reference for researchers in the near future.

\section{INTRODUCTION}

The collection of biodiversity data over large geographical areas is essential in order to adequately inform conservation policy (Chiarucci et al. 2011, Schmeller et al. 2015). Great efforts have been made in recent years to integrate biodiversity information from thousands of sources into global data depositories, such as the Global Biodiversity Information Facility (GBIF 2019) and the Map of Life (MOL 2019), among others. These depositories gather a huge amount of open access data, and thus allow scientists to address relevant issues on biodiversity and conservation. However, an aspect that is sometimes neglected is that differences with respect to data sampling, storage and mobilization often lead to bias in large-scale biodiversity patterns (Beck et al. 2014).

Biodiversity data are compiled in very different ways across Europe (Voříšek \& Marchant 2003, EuMon 2019). In Western and Central European countries, citizen science - understood as a strong partnership between amateur and professional scientists - has constituted a fundamental pillar for the compilation of biodiversity data (Bell et al. 2008, Dickinson et al. 2010). In contrast, the tradition of data collection in the eastern half of Europe and the Balkans has been often based on professional work directed by academies of science or similar governmental institutions (e.g. Budinski et al. 2010). In addition, methodological differences among countries are influenced by socio-political contexts, specific national targets, fieldwork and data mobilization approaches, and geographical particularities.

Conscious of the value of integrating national data to aid the understanding of largescale patterns of distribution and abundance in birds, European ornithologists have a long tradition of cooperation among national organizations. Developing from a series of meetings aimed at greater international collaboration in ornithology, the European 
91 Ornithological Atlas Committee (EOAC) was set up in 1972. Its representatives soon realized that a Europe-wide atlas could be produced from national surveys if common standards were adopted (see Greenwood 2017). The EOAC later changed its name and formalized its organizational structure to become the European Bird Census Council (EBCC), the organization that produced the EBCC Atlas of European Breeding Birds (Hagemeijer \& Blair 1997), hereafter named EBBA1.

EBBA1 integrated data on the distribution and abundance of breeding birds, compiled at national level, into a single pan-European collaborative work. Thanks to the coordinated efforts of thousands of ornithologists and birdwatchers, accurate information on distribution and abundance was gathered for 495 species in 3950 $50 \times 50 \mathrm{~km}$ squares (Figure 1). After publication EBBA1 data were made accessible to researchers, first under direct request to the EBCC Executive Committee and, since 2015, as open access via GBIF. EBBA1 has represented one of the few sources of information concerning distribution of bird populations at a continental scale and consequently has been widely employed in fundamental and applied research and for conservation-oriented publications (e.g. BirdLife International 2004). However, an analysis of the use of EBBA1 in research to assess its impact in the scientific community has not been done.

In this paper we show the potential of using such pan-European distribution data in research. More specifically, we review how EBBA1 was used in scientific literature and what the aims of these studies were. At the moment of writing this article, the Second European Breeding Bird Atlas (EBBA2) (Keller 2014, EBBA2 2019) is finalizing the compilation of updated data on the distribution of all breeding bird species (Figure 1). Following this review of literature we discuss how this knowledge has been incorporated in the aims, organization and methodological choices for the EBBA2 project. Finally, we show our vision of current efforts in the integration of continental bird data and anticipate how EBBA2 will contribute to basic and applied research. 
MATERIALS AND METHODS

120

121

122

123

124

We considered Google Scholar as our source of information to analyse the use of EBBA1 in scientific publications. This search facility is freely and easily accessible, provides similar results to Thompson's ISI Citation Index (Pauly \& Stergiou 2005), and it has become increasingly popular in recent years (de Winter et al. 2014). We conducted the literature search in December 2016. We queried the sequence of words 'EBCC Atlas of European Breeding Birds' and downloaded results in a database. Despite the potential scientific interest of information collected in books, theses, technical reviews and 'grey' literature, we removed these types of works from the original database and kept only papers published in scientific journals. Then we performed a random selection of 100 papers from the total available using the Wichmann-Hill number generator (Wichmann \& Hill 1982). Selected papers (shown with a symbol * in this article) were read by $\mathrm{SH}$ to analyse the general use of EBBA1 in science.

We addressed three specific questions related to how EBBA1 was used in scientific publications:

- Was EBBA1 used only for its information about birds? Or did it also attract researchers' attention regarding the way the project was organised?

- Were EBBA1 data re-analysed in these scientific publications?

- When new analyses of EBBA1 were performed, what were the purposes?

In addition, we addressed five questions related to the subject matter of the papers that cited EBBA1:

- What were the major research topics of papers that cited EBBA1? 
- What were the pressures on biodiversity addressed in the papers that cited EBBA1?

- Was EBBA1 used more often in papers that studied observed change in the past or predicted future change?

- Was EBBA1 more often used in international, national or subnational studies?

- Was EBBA1 more often used in studies about a single bird species, multiple bird species or studies that included several groups (birds plus others)?

\section{RESULTS}

\section{How EBBA1 was used in scientific publications}

Our search in Google Scholar showed that 3150 scientific papers published in journals referred to 'EBCC Atlas of European Breeding Birds'. From the 100 papers randomly selected for this study 87 papers were in written in English and 13 in nine other languages: German (5), Russian (1), Spanish (1), French (1), Italian (1), Polish (1), Dutch (1), Catalan (1) and Norwegian (1). All these papers are listed in Appendix I.

A total of 96 papers analysed in this study were interested in the EBBA1 data on breeding bird species and four papers focused on the methodology and on how the project was organized. A total of 76 papers referred to the general patterns of species distribution, abundance or ecology shown in EBBA1, but did not use atlas data to conduct new analyses. Nevertheless, 19 papers re-analysed EBBA1 data for three main purposes: analyses of species distribution (8 papers), determining species ecological traits (7) and analyses focusing on population sizes (4).

\section{Subject matter of the papers that cited EBBA1}

\section{Main topics}

EBBA1 was cited for many different scientific purposes within the field of biodiversity research. Nevertheless, two topics stood out: species distribution (50 papers) and 
ecology (44 papers). Other topics such as climate, conservation, trends or abundance were addressed by a smaller number of papers (Figure 2).

\section{Pressures on biodiversity}

Climate change was the environmental pressure more frequently reported in papers referencing EBBA1, accounting for a total of 12 papers. Concern on how changes in agricultural practices are affecting farmland birds was the topic of five papers, habitat loss and environmental impact associated with invasive alien species were studied in four papers each and pollution was addressed in three papers.

\section{Temporal focus}

EBBA1 was a reference for 22 papers that incorporated an assessment of temporal change in past-to-present approaches. Future projections were at least partly addressed in five papers.

\section{Scale}

Our survey showed that 54 of the analysed papers studied patterns at subnational level, 28 papers at national level; 18 papers worked at the European scale (or substantial part of the continent) and five addressed research at the global scale.

\section{Spatial resolution}

EBBA1 presented the data in a relatively coarse $50 \times 50 \mathrm{~km}$ grid. Among the studies citing EBBA1, 16 studied biogeographical or macroecological patterns at the same spatial resolution used in this atlas. In 25 papers analyses were conducted at finer resolutions, usually using EBBA1 as background information but in few cases reanalysing its data and then applying the results at finer resolution.

\section{Biodiversity focus}


EBBA1 was cited predominantly in papers on birds, namely in 48 papers on single species and 46 treating several species. Five papers focused on birds and other biological groups. Only one paper was not interested in birds but exclusively in plants.

\section{DISCUSSION}

\section{How EBBA1 was used in scientific publications}

Our analyses show that EBBA1 was used in very different ways. Very often EBBA1 was employed as background information for studies about a particular species, such as that of the status of the Bearded Parrotbill Panurus biarmicus in Italy (Brichetti \& Grattini 2008)*or the decline of the Red-backed Shrike Lanius collurio in Zealand, Denmark (Pedersen et al. 2011)*. In other cases, EBBA1 information was viewed in a wider context and represented a general reference for the distribution of groups of bird species, such as for the ranges of boreal birds (Virkkala \& Rajasärkkä 2007)*. A substantial proportion of the sampled papers not only cited EBBA1 data but presented novel analyses using it. Some of the papers that re-analysed the data were interested in deriving information on species distribution. For example, EBBA1 data were used (together with data from the Atlas of Southern African Birds, Harrison et al. 1997), to model species distributions at the Last Glacial Maximum and then analyse the contrasting late-Quaternary histories for Southern and Northern Hemisphere bird species (Huntley et al. 2013)*. EBBA1 was also used to derive species ecological traits based on the species' respective distributions. For example Gaüzère et al. (2015)* used EBBA1 data to calculate species-specific temperature indexes (STI), representing the preferred climate conditions of species based on temperatures within their area of

212 distribution and then showed a fine-scale and short-term adjustment of community

213 composition to temperature changes. An example of EBBA1 data use to derive

214 information on species population size is the study of Møller et al. (2011)* who 
215 obtained population sizes from this atlas to determine that migratory divides constitute

216 barriers to dispersal with consequences for ecology and evolution of populations.

\section{Topics in papers referring to EBBA1}

\section{Main topics}

219 EBBA1 was widely used as a reference for bird species distribution, population size and ecology in many scientific publications interested in a variety of scientific topics. Many distributional studies conducted at national or regional scales referred to EBBA1 to provide a wide geographical context for the species of interest. This background information was applied in a variety of circumstances, such as the delimitation of Important Bird Areas (IBAs) in Macedonia (Velevski et al. 2010)* and the distribution of birds of prey in Belarus (Dombrovski \& Ivanovski 2005)*. Information from EBBA1 was widely used as a suitable reference in papers on species ecology. A first example is a study that used bird-land cover associations based on EBBA1 data in order to determine the influence of this predictor (and others) on beta diversity for European birds (Keil et al. 2012)*. A second example is the use of EBBA1 as a reference for the habitat preferences of Dartford Warbler Sylvia undata in the context of assessing its status in the UK (Wotton et al. 2009)*.

Conservation also emerged as a very relevant topic and information from EBBA1 was used for a wide variety of purposes. For instance, the evaluation of the network of

234 protected areas by Sándor \& Domşa $(2012)^{*}$ who determined additional areas to better 235 preserve forest specialist birds on the basis of a thorough analysis of habitat preferences, the assessment of species of conservation concern as described by Keller et al. (2010)* who assessed the international importance of the breeding populations of bird species in Switzerland by estimating the percentage of the national population using EBBA1 as reference, and the evaluation of land use policies as described by 
240 Eggers et al. (2009)* who used the EBBA1 dataset to evaluate whether biofuel policies

241 were detrimental to biodiversity in agricultural landscapes in Europe.

\section{Pressures on biodiversity}

243 Five out of the six main categories of environmental pressure according to Aichi Target

244 B (Secretariat of the Convention on Biological Diversity 2014) were found as topics in

245 the analysed papers, namely climate change, agricultural practices, habitat loss,

246 invasive alien species and pollution. EBBA1 data had a prominent role in modelling

247 climatic ranges of bird species in the context of predictions of impact of climate change

248 on their populations either at continental (e.g. Huntley et al. 2004)*, national (e.g. Reif

249 et al. 2013, Koleček et al. 2014)* and local level (e.g. Flousek et al. 2015)*. Beyond our

250 random selection of papers in journals, it is noticeable to mention that EBBA1 was

essential to model European species distributions under future climatic scenarios

252 (Huntley et al. 2008). Effects of agricultural practices on birds was also addressed by

253 some of the analysed papers. For instance, Meller et al. (2015)* used EBBA1 data and

254 predicted that the magnitude of range shifts due to climate change was far greater than

255 the impact of land conversion to bioenergy plantations within the European Union.

256 Temporal focus

257 Since EBBA1 maps provided just a single time reference, and there is no comparable 258 data source for another period yet, no study used the data from this atlas to explicitly

259 analyse temporal changes in bird distribution. However, some authors used the

260 information written in the species accounts in EBBA1 to describe general patterns of

261 distribution or population change, such as in the study of the decline in Tree Sparrow

262 Passer montanus populations in Poland (Tomiałojć 2012)*. EBBA1 data were cited in

263 several publications to project species distributions into the future, such as the

264 prediction of a considerable risk of extinction within the Bavarian Forest National Park

265 as a result of global warming (Bässler et al. 2010). 
267 To date EBBA1 is certainly among the most relevant original works that map the occurrence of breeding birds in the whole of Europe. Therefore, it has been widely employed as a key reference for the European distribution of birds in studies carried out at subnational, national, continental and global scales. For example, Chiron et al. $(2009)^{*}$ used EBBA1 data to explore the relationship between the geographical pattern of richness of native bird species and that of exotic bird species in Europe. However, EBBA1 was mostly used as a reference concerning species distribution at subnational level, such as in the study of the impact of radiation from the Chernobyl Nuclear Power

275 Plant on birds by Møller et al. (2010)*.

\section{Spatial resolution}

277 The detail at which a geographical dataset defines the location of its features is a key 278 element for studies on species distribution. EBBA1 provided data in a 50x50 km grid 279 and, as shown in many of the examples mentioned so far, this cell size met the needs 280 of many of the analyses required to make progress in diverse fields of the ornithology. 281 For example, Carrascal \& Seoane $(2009)^{\star}$ aggregated original $10 \times 10 \mathrm{~km}$ data for 282 Bonelli's Eagle Aquila fasciata from a Spanish atlas to a coarser $50 \times 50 \mathrm{~km}$ resolution 283 because they considered that in the context of analysing of factors affecting its 284 distribution in Spain, the latter provided a higher certainty about the species occurrence 285 in each cell (absences more likely to be real).

286 Biodiversity focus

287 EBBA1 has undoubtedly created one of the most complete databases on the 288 distribution of birds in Europe. Other large-scale studies have reached a similar status 289 for other taxonomic groups. Together they have conformed an excellent dataset for 290 many studies interested in biodiversity in a broader sense. For example, Huntley et al. 
$291(2004)^{*}$ used distribution data from plants, birds and insects to predict that climatic 292 model performance was related neither to major taxonomic group nor to trophic level.

\section{PERSPECTIVES FOR THE NEW EUROPEAN BREEDING BIRD ATLAS}

295

296

297

At the moment of compiling information for the analyses shown in this article, a total of 3150 scientific journal papers referred to the 'EBCC Atlas of European Breeding Birds'. A new Google Scholar search would find that this is clearly an outdated number. All these values illustrate the recognition EBBA1 has received in the scientific community, but also the very high research potential of an atlas update.

The analysis of publications citing EBBA1 revealed issues that are important to be taken into account for other projects and in particular for the Second European Breeding Bird Atlas, hereafter called EBBA2. Some of the papers analysed in this study made specific comments on the limitations of EBBA1 data, referring especially to deficiencies in the coverage, such as in the eastern part of the continent and the Balkans (e.g. Keil et al. 2012)*. EBBA1 gaps of information resulted mainly from limitations in coordination, fieldwork capacity and data flow at that time. To launch the new project and update in the best possible manner the EBBA1 information, EBCC constituted an EBBA2 steering committee whose members had experience in organising surveys, analising the data and interpreting the results. These members came from different parts of Europe because bird atlas approaches differ depending on the biogeographical, cultural, traditional and economic contexts (Greenwood 2007). Then, an EBBA2 coordination team was established to deliver the central functions of running the atlas project and of keeping a fluent communication within the network of scientists developing methodologies at the European level, coordinators organising fieldwork at national level and skilled ornithologists doing the fieldwork. This close 
collaboration guaranteed the top-down integration from a bottom-up approach taking

317 the very diverse situation in Europe into account (Herrando et al. 2014).

318 The analysis of the papers that cited EBBA1 showed that many studies focused on

319 changes in occurrence. However, none could use that dataset to study changes in

320 distribution (see Temporal focus). Updating EBBA1 information will provide many

321 opportunities to analyse changes in distribution and, thus to investigate the

322 environmental pressures driving these changes. Therefore, one of the most important

323 methodological aspects of EBBA2 was to maximize comparability between the two

324 atlases. Consequently, the same UTM 50x50 km grid, breeding codes and abundance

325 codes as used in EBBA1 were adopted for EBBA2. This grid was also selected in

326 compliance with projects working on other taxonomic groups, e.g. see Sillero et al.

327 (2014) for the new atlas of amphibians and reptiles of Europe, which will provide a

328 good basis for cross-taxa analyses in the future (see Biodiversity focus). However,

329 robust analyses of change do not only depend on the use of the same geographical

330 units but also on the particularities of the fieldwork done in each square in each atlas.

331 To overcome this difficulty, EBBA1-EBBA2 species distribution change was

332 incorporated in the EBBA2 project by means of taking into account information on the

333 fieldwork process for the two atlases. In fact, change was not calculated for all squares

334 but for a subsample that were sufficiently well covered in the two atlases. These

335 squares were determined after a series of analyses that incorporated information on

336 the reported completeness of coverage and the total number of species detected as

337 well as their deviance from modelled expected richness, among others. Finally, in the

338 overall framework of improving the quality of the data, EBBA2 implemented a novel

339 approach by incorporating highly standardised surveys within a sample of $10 \times 10 \mathrm{~km}$

340 squares. The more immediate aim of this survey was to generate detailed maps of

341 species breeding occurrence (see next paragraph), but these standardised surveys 
342 could provide potential added value for robust comparisons in the future (see approach

343 implemented for this purpose in Balmer et al. 2013).

344 Gaston et al. $(2008)^{*}$ pointed out that, despite the progress made by EBBA1 for the

345 quantitative assessment of species ranges, this coarse resolution limited its direct

346 value for most practical conservation planning exercises. The higher the resolution the

347 better the inferences that can be made concerning issues like distribution (e.g.

348 presence in protected areas) and ecology (e.g. habitat requirements, climatic niches).

349 Thus, in addition to the compilation of data at the $50 \times 50 \mathrm{~km}$ scale, a protocol to collect

350 standardized data across the whole of Europe was implemented in EBBA2 which

351 allowed modelling of species occurrence at a resolution of $10 \times 10 \mathrm{~km}$. This information

352 was mostly derived from timed visits (complete lists of species obtained at a given site

353 and in given time) specifically designed for atlas work and from standardized common

354 bird monitoring schemes. Given the complexity of the data, with many different sources,

355 field methods and intensities of coverage across Europe, the EBCC convened a group

356 of experts in a "Spatial Modelling Group" (SMOG) to approach this pan-European

357 spatial distribution modelling in the best possible way. A final selection of more than 35

358000 EBBA2 standard surveys obtained in over 17000 different $10 \times 10 \mathrm{~km}$ squares was

359 available for modelling (Figure 3). This dataset incorporated several elements to allow

360 the robust assessment of the detection probability for many species, i.e. repeated visits

361 at a sample of available squares, date, field method and duration of the survey. A total

362 of 40 environmental predictors, plus detection probability, were used to model species

363 distribution averaging 10 different models (see Figure 4 for an example for Turtle Dove

364 Streptopelia turtur). Finally, a cross-validation procedure was conducted in order to

365 quantify the predictive accuracy of the model (Herrando et al. 2017).

366

367

Outlook for research 
368 The present study documents the applications of EBBA1 in scientific publications and 369 provides examples of why and how researchers may approach the coming EBBA2 data.

370 This provides the possibility to forge an early connection with future research and encourage new ideas on how the new data can be used and how to increase the use of papers using this data. At the time of writing this article EBBA2 is still an ongoing project. The plan is to publish a book by late 2020 and produce a web-based product

374 some time after publication.

We are convinced that EBBA2 will deliver data and information that will offer excellent and unique opportunities for further scientific analyses and publications. Spatio-

377 temporal comparisons based on the atlas data are a powerful asset that could be 378 applied to understand population dynamics of breeding birds across Europe. We see ample opportunities for use concerning the major topics that already have been addressed using the EBBA1 data, including environmental pressures according to Aichi Target B (see Pressures on biodiversity), such as impacts of climate and land-use changes or the spread of invasive (bird) species. Other subjects of interest could be the effects of the Natura2000 network and other conservation policies, identification of new priority areas for conservation, determination of species hotspots (also concerning other taxonomic groups), risks associated with propagation of zoonoses, and flyway research.

Within the context of biodiversity declines across Europe, the new European Breeding Bird Atlas represents a unique opportunity for researchers and policy makers to deliver valuable research to underpin conservation action across the continent. We are confident that, as it happened with its predecessor, EBBA2 will become a landmark for bird conservation in this region. 
We would like to thank a lot here all national coordinators and data providers as well as ten-thousands of ornithologists and birdwatchers across Europe that built EBBA1 a few decades ago and those that are now making EBBA2 possible! We also thank the many organisations and people that provided financial support in both projects.

\section{REFERENCES}

1. Balmer, D.E., Gillings, S., Caffrey, B.J., Swann, R.L., Downie, I.S. \& Fuller, R.L. 2013. Bird Atlas 2007-11: the breeding and wintering birds of Britain and Ireland. BTO Books, Thetford.

2. Bässler, C., Müller, J., Hothorn, T., Kneib, T., Badeck, F. \& Dziock, F. 2010. Estimation of the extinction risk for high-montane species as a consequence of global warming and assessment of their suitability as cross-taxon indicators. Ecol. Indic. 10: 341-352.

3. Beck, J., Böller, M., Erhardt, A. \& Schwanghart, W. 2014. Spatial bias in the GBIF database and its effect on modelling species' geographic distributions. Ecol. Inform. 19: 10-15.

4. Bell, S., Marzano, M., Cent, J., Kobierska, H., Podjed, D., Vandzinskaite, D., Reinert, H., Armaitiene, A., Grodzińska-Jurczak, M. \& Muršič, R. 2008. What counts? Volunteers and their organisations in the recording and monitoring of biodiversity. Biodivers. Conserv. 17: 3443-3454.

5. BirdLife International. 2004. Birds in Europe: Population Estimates, Trends and Conservation Status. BirdLife Conservation Series No 12.

6. Brichetti, P. \& Grattini, N. 2008. Distribuzione, consistenza ed evoluzione delle popolazioni di basettino Panurus biarmicus nidificanti in Italia nel periodo 1980-2006. Avocetta 32: 47-53 (in Italian). 
7. Budinski, I., Čulina, A., Mikulić, K. \& Jurinović, L. 2010. Bird species that have significantly changed breeding range on Croatian coastal area: comparison of 30 years old data and recent knowledge. Bird Census News 23: 49-58.

8. Carrascal, L.M. \& Seoane, J. 2009. Factors affecting large-scale distribution of the Bonelli's eagle Aquila fasciata in Spain. Ecol. Res. 24: 565-573.

9. Chiarucci, A., Bacaro, G. \& Scheiner, S.M. 2011. Old and new challenges in using species diversity for assessing biodiversity. Philos. Trans. R. Soc. Lond., B, Biol. Sci. 366: 2426-2437.

10. Chiron, F., Shirley, S. \& Kark, S. 2009. Human-related processes drive the richness of exotic birds in Europe. Proc. Royal Soc. B 276: 47-53.

11. de Winter, J.C.F., Zadpoor, A.A. \& Dodou, D. 2014. The expansion of Google Scholar versus Web of Science: a longitudinal study. Scientometrics 98: 15471565.

12. Dickinson, J.L., Zuckerberg, B. \& Bonter, D.N. 2010. Citizen science as an ecological research tool: challenges and benefits. Annu. Rev. Ecol. Evol. Syst. 41: 149-172.

13. Dombrovski, V. C. \& Ivanovski, V.V. 2005. New data on numbers and distribution of birds of prey breeding in Belarus. Acta Zool. Litu. 15: 218-227.

14. EBBA2. 2019. http://ebba2.info

15. Eggers, J., Tröltzsch, T., Falcucci, A., Maioranow, L., Verburgz, P.H., Framstad, E., Louette, G., Maes, D., Szabolcs, N., Ozinga, W. \& Delbaere, B. 2009. Is biofuel policy harming biodiversity in Europe? Glob. Change Biol. Bioenergy 1: 18-34.

16. EuMon. 2019. EU-wide monitoring methods and systems of surveillance for species and habitats of community interest. http://eumon.ckff.si/ 
17. Flousek, J., Telenský, T., Hanzelka, J. \& Reif, J. 2015. Population trends of Central European montane birds provide evidence for adverse impacts of climate change on high-altitude species. PLOS ONE 10: e0139465. 2008. Protected areas in Europe. Ann. New York Acad. Sci. 1134: 97-119.

19. Gaüzère, P., Jiguet, F. \& Devictor, V. 2015. Rapid adjustment of bird community compositions to local climatic variations and its functional consequences. Glob. Change Biol. 21: 3367-3378.

20. GBIF. 2019. Global Biodiversity Information Facility. http://www.gbif.org/

21. Greenwood, J.J.D. 2007. Citizens, science and bird conservation. J. Ornithol. 148: 77-124.

22. Greenwood, J.J.D. 2017. The History of the EBCC Atlas of European Breeding Birds. Vogelwelt 137: 3-18.

23. Hagemeijer, W. \& Blair, M. 1997. The EBCC Atlas of European Breeding Birds. T. \& A.D. Poyser, London.

24. Harrison, J.A., Allan, D.G., Underhill, L.G., Herremans, M., Tree, A.J., Parker, V. \& Brown, C. 1997 The Atlas of Southern African Birds. BirdLife South Africa, Johannesburg.

25. Herrando, S., Keller, V., Voříšek, P., Kipson, M., Franch, M., Anton, M., Pla, 

Species distribution models indicate contrasting late-Quaternary histories for Southern and Northern Hemisphere bird species. Glob. Ecol. Biogeogr. 22: 277-288.

28. Huntley, B., Collingham, Y.C., Willis, S.G., \& Green, R.E. 2008. Potential impacts of climatic change on European breeding birds. PLOS ONE: 3: e1439.

29. Huntley, B., Green, R.E., Collingham, Y.C., Hill, J.K., Willis, S.G., Bartlein, P.J., Cramer, W., Hagemeijer, W.J.M. \& Thomas, C.J. 2004. The performance of models relating species geographical distributions to climate is independent of trophic level. Ecol. Lett. 7: 417-426.

30. Keil, P., Schweiger, O., Kühn, I., Kunin, W.E., Kuussaari, M., Settele, J., Henle, K., Brotons, L., Pe'er, G., Lengyel, S., Moustakas, A., Steinicke, H. \& Storch, D. 2012. Patterns of beta diversity in Europe: the role of climate, land cover and distance across scales. J. Biogeogr. 39: 1473-1486.

31. Keller, V. 2014. EBBA2 - A New European Atlas of Breeding Birds. Bird Census News 26: 3-5.

33. Koleček, J., Albrecht, T. \& Reif, J. 2014. Predictors of extinction risk of passerine birds in a Central European country. Anim. Conserv. 17: 498-506.

32. Keller, V., Ayé, R., Müller, W., Spaar, R. \& Zbinden, N. 2010. Die prioritären Vogelarten der Schweiz: Revision 2010. Ornithol. Beob. 107: 265-285 (in German).

34. Meller, L., Thuiller, W., Pironon, S., Barbet-Massin, M., Hof, A. \& Cabeza, M. 2015. Balance between climate change mitigation benefits and land use impacts of bioenergy: conservation implications for European birds. Glob. Change Biol. Bioenergy 7: 741-751.

35. MOL. 2019. Map of Life. https://mol.org/ 
36. Møller, A.P., Erritzøe, J., Karadas, F. \& Mousseau, T.A. 2010. Historical mutation rates predict susceptibility to radiation in Chernobyl birds. J. Evol. Biol. 23: $2132-2142$.

37. Møller, A.P., Garamszegi, L.Z., Peralta-Sánchez, J.M. \& Soler, J.J. 2011. Migratory divides and their consequences for dispersal, population size and parasite-host interactions. J. Evol. Biol. 24: 1744-1755.

38. Pauly, D. \& Stergiou, K.I. 2005. Equivalence of results from two citation analyses: Thomson ISI's Citation Index and Google's Scholar service. Ethics in Science and Environmental Politics 2005: 33-35.

39. Pedersen, P.E., Petersen, T.L., Jørgensen, P.S. \& Tøttrup, A.P. 2011. The breeding population of red-backed shrike Lanius collurio in Gribskov, Denmark. Dansk Ornitologisk Forenings Tidsskrift 105: 179-182.

40. Reif, J., Prylová, K., Šizling, A.L., Vermouzek, Z., Št'astný, K. \& Bejček, V. 2013. Changes in bird community composition in the Czech Republic from 1982 to 2004: increasing biotic homogenization, impacts of warming climate, but no trend in species richness. J. Ornithol. 154: 359-370.

41. Sándor, A.D. \& Domşa, C. 2012. Special protected areas for conservation of Romanian forest birds: Status assessment and possible expansion using predictive tools. Acta Zool. Bulgar.64: 367-374.

42. Secretariat of the Convention on Biological Diversity. 2014. Global Biodiversity Outlook 4. Montréal.

43. Schmeller, D.S., Julliard, R., Bellingham, P.J., Böhm, M., Brummitt, N., Chiarucci, A., Couvet, D., Elmendorf, S., Forsyth, D.M., García-Moreno, J., Gregory, R.D., Magnusson, W.E., Martin, L.J., McGeoch, M.A., Mihoub, J.B., Pereira, H.M., Proença, V., van Swaay, C.A.M, Yahara, T. \& Belnap, J. 2015. Towards a global terrestrial species monitoring program. J. Nat. Conserv. 25: 51-57. 
44. Sillero, N., Campos, J., Bonardi, A., Corti, C., Creemers, R., Crochet, P.-A., Isailović, J.C., Denoël, M., Ficetola, G.F., Gonçalves, J., Kuzmin, S., Lymberakis, P., de Pous, P., Rodríguez, A., Sindaco, R., Speybroeck, J., Toxopeus, B., Vieites, D.R. \& Vences, M. 2014. Updated distribution and biogeography of amphibians and reptiles of Europe. Amphibia-Reptilia 35: 1-31.

45. Tomiałojć, L. 2012. Changes in tree sparrow Passer montanus populations from urban parks. International Studies on Sparrows 36: 4-17.

46. Velevski, M., Hallmann, B., Grubač, B., Lisičanec, T., Stoynov, E., Lisičanec, E., Avukatov, V., Božič, L. \& Stumberger, B. 2010. Important bird areas in Macedonia: sites of Global and European importance. Acrocephalus 31: 181-282.

47. Virkkala, R. \& Rajasärkkä, A. 2007. Uneven regional distribution of protected areas in Finland: consequences for boreal forest bird populations. Biol. Conserv. 134: 361-371.

48. Voříšek P. \& Marchant J.H. 2003. Review of large/scale generic population monitoring schemes in Europe. Bird Census News 16: 16-40.

49. Wichmann, B.A. \& Hill, I.D. 1982. Algorithm AS 183: An Efficient and Portable Pseudo-Random Number Generator. J. Royal Stat. Soc. Series C (Applied Statistics) 31: 188-190. 
Random selection of 100 papers that cited the EBCC Atlas of European Breeding

Birds (EBBA1) that were used in this study to analyze the uses of this atlas in

1. Acquarone, C., Cucco, M. \& Malacarne, G. 2001. Short-term effects on body condition and size of immunocompetent organs in the Hooded Crow. Ital. J. Zool. 68: 195-199.

2. Ambrosini, R., Bolzern, A.M., Canova, L., Arieni, S., Møller, A.P. \& Saino, N. 2002. The distribution and colony size of barn swallows in relation to agricultural land use. J. Appl. Ecol. 39: 524-534.

3. Arzel, C., Dessborn, L., Pöysä, H., Elmberg, J., Nummi, P. \& Sjöberg, K. 2014. Early springs and breeding performance in two sympatric duck species with different migration strategies. Ibis 156: 288-298.

4. Backström, N. \& Väli, Ü. 2011. Sex- and species- biased gene flow in a spotted eagle hybrid zone. BMC Evol. Biol. 11: 100.

5. Balčiauskienè, L., Jovaišas, A., Naruševičius, V., Petraška, A. \& Skuja, S. 2006. Diet of Tawny Owl (Strix aluco) and Long-eared Owl (Asio otus) in Lithuania as found from pellets. Acta Zool. Litu. 16: 37-45.

6. Balmori, A., Cuesta, M.A. \& Caballero, J.M. 2002. Distribución de los mosquiteros Ibérico (Phylloscopus brehmii) y Europeo (Phylloscopus collybita) en los bosques de ribera de Castilla y León (España). Ardeola 49: 19-27.

7. Bässler, C., Müller, J., Hothorn, T., Kneib, T., Badeck, F. \& Dziock, F. 2010. Estimation of the extinction risk for high-montane species as a consequence of global warming and assessment of their suitability as cross-taxon indicators. Ecol. Indic. 10: 341-352. 
8. Battisti, C., Aglitti, C., Sorace, A. \& Trotta, M. 2006. Water level decrease and its effects on the breeding bird community in a remnant wetland in Central Italy. Ekologia 25: 252-263.

9. Birtsas, P., Sokos, C., Papaspyropoulos, K.G., Batselas, T., Valiakos, G. \&

578

579

580

581

582

583

584

585

586

587

588

589

590

591

592

593

594

595

596

597

598

599

600 Billinis C. 2013. Abiotic factors and autumn migration phenology of Woodcock (Scolopax rusticola Linnaeus, 1758, Charadriiformes: Scolopacidae) in a Mediterranean area. Ital. J. Zool. 80: 392-401.

10. Bordjan, D. \& Tome, D. 2014. Rain may have more influence than temperature on nest abandonment in the Great Tit Parus major. Ardea 102: 79-86.

11. Brichetti, P. \& Grattini, N. 2008. Distribuzione, consistenza ed evoluzione delle popolazioni di basettino Panurus biarmicus nidificanti in Italia nel periodo 1980-2006. Avocetta 32: 47-53 (in Italian).

12. Burton, N.H.K., Dodd, S.G. Clark, N.A. \& Ferns, P.N. 2002. Breeding origins of Redshank Tringa totanus wintering at two neighbouring sites on the Severn Estuary: evidence for partial racial segregation. Ringing \& Migration 21: 19-24.

13. Carrascal, L.M. \& Seoane, J. 2009. Factors affecting large-scale distribution of the Bonelli's eagle Aquila fasciata in Spain. Ecol. Res. 24: 565-573.

14. Chiron, F., Shirley, S. \& Kark, S. 2009. Human-related processes drive the richness of exotic birds in Europe. Proc. R. Soc. Lond., B, Biol. Sci. 276: 47-53.

15. Chmielewski, S. \& Iwanczuk, C. 2008. Liczebnosc ptakow szponiastych Falconiformes oraz kruka Corvus corax w krajobrazie rolniczym pod Mogielnica w roku 1981 i 2003. Kulon 13: 67-75 (in Polish).

16. Clark, H. \& Sellers, R.M. 2001. Biometrics of the Twite Carduelis flavirostris. Ringing \& Migration 20: 328-337.

17. Clark, J.A., Wernham, C.V., Balmer, D.E., Adams, S.Y., Griffin, B.M., Blackburn, J.R., Anning, D. \& Milne, L.J. 2001. Bird ringing in Britain and Ireland in 1999. Ringing \& Migration 20: 239-288. 
18. Crochet, P.A., Lebreton, J.D. \& Bonhomme, F. 2002. Systematics of large white-headed gulls: patterns of mitochondrial DNA variation in western European taxa. The Auk 119: 603-620.

19. Delgado, M.P., Traba, J. \& Morales, M.B. 2011. Climate niche constraints in two coexisting steppe birds: the little and the great bustards. Ardeola 58: 223238.

20. Dombrovski, V.C. \& Ivanovski, V.V. 2005. New data on numbers and distribution of birds of prey breeding in Belarus. Acta Zool. Litu. 15: 218-227.

21. Eggers, J., Tröltzsch, K., Falcucci, A., Maiorano, L., Verburg, P.H., 2009. Is biofuel policy harming biodiversity in Europe? Glob. Change Biol. Bioenergy 1: 18-34.

22. Elmberg, J., Nummi, P., Pöysä, H. \& Sjöberg, K. 2003. Breeding success of sympatric dabbling ducks in relation to population density and food resources. Oikos 100: 333-341.

23. Exo, K.M., Becker, P.H. \& Sommer, U. 1998. Umweltchemikalien in Eiern von Binnenland-und Wattenmeerbrütern des Austernfischers (Haematopus ostralegus). J. Ornithol. 139: 401-405 (in German).

24. Felton, A., Lindbladh, M., Elmberg, J., Felton, A.M., Andersson, E., Sekercioglu, C.H., Collingham, Y. \& Huntley, B. 2014. Projecting impacts of anthropogenic climatic change on the bird communities of southern Swedish spruce monocultures: will the species poor get poorer? Ornis Fennica 91: 1-13.

25. Finney, S.K., Wanless, S., Harris, M.P. \& Monaghan, P. 2001. The impact of gulls on puffin reproductive performance: an experimental test of two management strategies. Biol. Conserv. 98: 159-165.

26. Flousek, J., Telenský, T., Hanzelka, J. \& Reif, J. 2015. Population trends of Central European montane birds provide evidence for adverse impacts of climate change on high-altitude species. PLOS ONE 10: e0139465. 
27. Fox, A.D., Ramo, C., Varo, N., Sánchez, M.I., Amat, J.A. \& Green, A.J. 2013. Late-moulting Black-necked Grebes Podiceps nigricollis show greater body mass in the face of failing food supply. Ibis 155: 814-822.

28. Gainzarain, J.A., Arambarri, R. \& Rodríguez, A.F. 2002. Population size and factors affecting the density of the Peregrine Falcon Falco peregrinus in Spain. Ardeola 49: 67-74.

29. Gaston, K. J., Jackson, S. F., Nagy, A., Cantú-Salazar, L. \& Johnson, M. 2008. Protected areas in Europe: principle and practice. Ann. N. Y. Acad. Sci. 1134: $97-119$.

30. Gaüzère, P., Jiguet, F. \& Devictor, V. 2015. Rapid adjustment of bird community compositions to local climatic variations and its functional consequences. Glob. Change Biol. 21: 3367-3378.

31. Gibbons, D.W. 2000. Development of Pan-European breeding bird monitoring. The Ring 22: 25-33.

32. Gradev, G., García, V., Ivanov, I., Zhelev, P. \& Kmetova, E. 2012. Data from Egyptian vultures Neophron percnopterus tagged with GPS/GSM transmitters in Bulgaria. Acta Zool. Bulgar. 4: 141-146.

33. Grussu, M. 1999. Swamp-hen in Italy. British Birds 92: 183-192.

34. Guzmán, J.L., Ferrand, Y. \& Arroyo, B. 2011. Origin and migration of woodcock Scolopax rusticola wintering in Spain. Eur. J. Wildlife Res. 57: 647655.

35. Heylen, D., Sprong, H., Oers, K., Fonville, M., Leirs, H. \& Matthysen, E. 2014. Are the specialized bird ticks, Ixodes arboricola and I. frontalis, competent vectors for Borrelia burgdorferi sensu lato? Environ. Microbiol. 16: $1081-1089$.

36. Huntley, B., Allen, J.R., Barnard, P., Collingham, Y.C. \& Holliday, P.R. 2013. Species distribution models indicate contrasting late-Quaternary histories for 

277-288.

37. Huntley, B., Green, R.E., Collingham, Y.C., Hill, J.K., Willis, S.G., Bartlein, P.J., Cramer, W., Hagemeijer, W.J.M. \& Thomas, C.J. 2004. The performance of models relating species geographical distributions to climate is independent of trophic level. Ecol. Lett. 7: 417-426.

38. Jenkins, R.K. \& Ormerod, S.J. 2002. Habitat preferences of breeding Water Rail Rallus aquaticus. Bird Study 49: 2-10.

39. Keil, P., Schweiger, O., Kühn, I., Kunin, W.E., Kuussaari, M., Settele, J., 665 Henle, K., Brotons, L., Pe'er, G., Lengyel, S., Moustakas, A., Steinicke, H. \& Storch, D. 2012. Patterns of beta diversity in Europe: the role of climate, land cover and distance across scales. J. Biogeogr. 39: 1473-1486.

40. Keil, P., Wilson, A.M., \& Jetz, W. 2014. Uncertainty, priors, autocorrelation

41. Keller, V. 2000. Winter distribution and population change of Red-crested Pochard Netta rufina in southwestern and central Europe. Bird Study 47: 176185.

42. Keller, V., Ayé, R., Müller, W., Spaar, R. \& Zbinden, N. 2010. Die prioritären Vogelarten der Schweiz: Revision 2010. Ornithol. Beob. 107: 265-285 (in German). specialists: 100 years of changes in community composition in an island biogeographical study. Divers. Distrib. 15: 641-648.

44. Koleček, J., Albrecht, T. \& Reif, J. 2014. Predictors of extinction risk of passerine birds in a Central European country. Anim. Conserv. 17: 498-506.

45. Konter, A. \& Konter, M. 2006. Migration patterns and site fidelity of European Grebes Podicipedidae. Regulus 21: 1-17. 
46. Kosinski, Z. 2001. The breeding ecology of the Greenfinch Carduelis chloris in urban conditions (study in Krotoszyn, W Poland). Acta Ornithol. 36: 111-121.

47. Llabrés, X. 2010. Cria possible de pinsà trompeter Bucanetes githagineus a Mallorca. Anuari Ornitològic de les Balears 25: 51-55 (in Catalan).

48. Lovászi, P., Bártol, I., \& Moskát, C. 2000. Nest-site selection and breeding success of the Lesser Grey Shrike (Lanius minor) in Hungary. The Ring 22: 157-164.

49. Marti, J. 2007. Zur Habitatwahl des Waldlaubsängers Phylloscopus sibilatrix im Kanton Glarus. Ornithol. Beob. 104: 45-52 (in German).

50. Mattes, H. \& Gatter, W. 2011. Beeinflusst der Star Sturnus vulgaris über Höhlenkonkurrenz die Häufigkeit von Spechten Dendrocopos sp.? Ornithol. Beob. 108: 251-259 (in German).

51. Mazgajski, T.D. 2002. Nesting phenology and breeding success in great spotted woodpecker Picoides major near Warsaw (Central Poland). Acta Ornithol.37: 1-5.

700

52. Meller, L., Thuiller, W., Pironon, S., Barbet-Massin, M., Hof, A. \& Cabeza, M.

53. Meltofte, H., Durinck, J., Jakobsen, B., Nordstrom, C. \& Riget, F.F. 2006. impacts of bioenergy: conservation implications for European birds. Glob. Change Biol. Bioenergy 7: 741-751.

Trends in wader populations in the East Atlantic flyway as shown by numbers of autumn migrants in W Denmark, 1964-2003. Wader Study Group Bulletin 109: 111-119.

54. Mestecăneanu, A. \& Mestecăneanu, F. 2011. Researches regarding the influence of the weather on the flight of the white storks (Ciconia ciconia) in the spring migration across the Doamnei River hydrographical basin (Argeş County, Romania). Fascicula Biologie 18: 81-87. 

2003. Ornis Norvegica 28: 4-50 (in Norwegian).

56. Møller, A.P., Erritzøe, J., Karadas, F. \& Mousseau, T.A. 2010. Historical mutation rates predict susceptibility to radiation in Chernobyl birds. J. Evol. Biol. 23: 2132-2142.

57. Møller, A.P., Garamszegi, L.Z., Peralta-Sánchez, J.M. \& Soler, J.J. 2011. Migratory divides and their consequences for dispersal, population size and parasite-host interactions. J. Evol. Biol. 24: 1744-1755. changes and breeding bird assemblages in northwestern Portugal: the role of fire. Landsc. Ecol. 16: 175-187.

59. Morelli, F. 2015. Indicator species for avian biodiversity hotspots: Combination of specialists and generalists is necessary in less natural environments. J. Nat. Conserv. 27: 54-62.

60. Müller-Buser, M. 2000. Auftreten und Verschwinden der Sperbergrasmücke Sylvia nisoria bei Ramosch im Unterengadin zwischen 1987 und 1999. Ornithol. Beob. 97: 233-242 (in German).

61. Murgui, E. 2001. Factors influencing the distribution of exotic bird species in Comunidad Valenciana (Spain). Ardeola 48: 149-160.

62. Nankinov, D.N. 1998. Wood Sandpiper Tringa glareola and Green Sandpiper Tringa ochropus in Bulgaria. International Wader Studies 10: 370-374.

63. Neto, J.M. \& Correia, E. 2013. Biometrics and Sub-Specific Identification of White-Spotted Bluethroats Luscinia svecica cyanecula and L. s. namnetum During Autumn and Winter. Ardeola 59: 309-315.

64. Osiejuk, T.S., Olech, B., Ratyńska, K., Owsiński, A. \& GromadzkaOstrowska, J. 2004. Effects of season, plasma testosterone and body size on corncrake (Crex crex) call rhythm. Annales Zoologici Fennici 41: 647-659. 
65. Palomino, D., Carrascal, L.M. \& Potti, J. 2011. Distribution of Azure-winged Magpies Cyanopica cooki in Spain: both local and large-scale factors considered. Acta Ornithol. 46: 68-79.

66. Papeş, M. 2007. Ecological niche modeling approaches to conservation of endangered and threatened birds in Central and Eastern Europe. Biodiversity Informatics 4: 14-26.

67. Pedersen, P.E., Petersen, T.L., Jørgensen, P.S. \& Tøttrup, A.P. 2011. The breeding population of red-backed shrike Lanius collurio in Gribskov, Denmark. Dansk Ornitologisk Forenings Tidsskrift 105: 179-182.

68. Perkins, A.J., Hancock, M.H., Butcher, N. \& Summers R.W. 2005. Use of time-lapse video cameras to determine causes of nest failure of Slavonian Grebes Podiceps auritus. Bird Study 52: 159-165.

69. Piersma, T. \& van Der Velde, M. 2009. Breeding season-specific sex diagnostics in the monomorphic House Martin Delichon urbicum. Bird Study 56: $127-131$.

70. Polo, V., Carrascal, L.M., \& Metcalfe, N.B. 2007. The effects of latitude and day length on fattening strategies of wintering coal tits Periparus ater (L.): a field study and aviary experiment. J.Anim. Ecol. 76: 866-872.

71. Preston, C.D. 2013. Following the BSBI's lead: the influence of the Atlas of the British flora, 1962-2012. New J. Bot. 3: 2-14.

72. Procházka, P. \& Reif, J. 2002. Movements and settling patterns of Sedge Warblers (Acrocephalus schoenobaenus) in the Czech Republic and Slovakiaan analysis of ringing recoveries. The Ring 24: 3-13. 2006. Etude phénologique et variabilité interannuelle d'abondance des Charadriidés (Aves, Charadrii) dans un site Ramsar du Maroc: la Merja Zerga. Bulletin de l'Institut Scientifique 28: 35-47 (in French). 
74. Randler, C. 2003. Reactions to human disturbances in an urban population of the Swan Goose Anser cygnoides in Heidelberg (SW Germany). Acta Ornithol. 38: 47-52.

75. Reif, J. \& Flousek, J. 2012. The role of species' ecological traits in climatically driven altitudinal range shifts of central European birds. Oikos 121: 1053-1060.

76. Reif, J., Prylová, K., Šizling, A.L., Vermouzek, Z., Št’astný, K. \& Bejček, V. 2013. Changes in bird community composition in the Czech Republic from 1982 to 2004: increasing biotic homogenization, impacts of warming climate, but no trend in species richness. J. Ornithol. 154: 359-370.

77. Rönkä, N., Kvist, L., Pakanen, V.M., Rönkä, A., Degtyaryev, V., Tomkovich, P., Tracy, D. \& Koivula, K. 2012. Phylogeography of the Temminck's Stint (Calidris temminckii): historical vicariance but little present genetic structure in a regionally endangered Palearctic wader. Divers. Distrib. 18: 704-716.

78. Salit, K. \& Sol, D. 2005. Establishment success across convergent Mediterranean ecosystems: an analysis of bird introductions. Conserv. Biol. 19: $1519-1527$.

79. Sándor, A.D. \& Domşa, C. 2012. Special protected areas for conservation of Romanian forest birds: Status assessment and possible expansion using predictive tools. Acta Zool. Bulgar.64: 367-374.

80. Schaub, M., Pradel, R., Jenni, L. \& Lebreton, J.D. 2001. Migrating birds stop over longer than usually thought: an improved capture-recapture analysis. Ecology 82: 852-859.

81. Schekkerman, H. \& Visser, G.H. 2001. Prefledging energy requirements in shorebirds: energetic implications of self-feeding precocial development. The Auk 118: 944-957.

82. Schifferli, L., Spaar, R. \& Koller, A. 2006. Fence and plough for Lapwings: Nest protection to improve nest and chick survival in Swiss farmland. Osnabrücker Nat. Wiss. Mitt. 32: 123-129 (in German). 

López-Jurado, L.F. 2014. Density, nest site characteristics and breeding rates of the osprey (Pandion haliaetus) in the southern limit of its range in the Western Palearctic (Boa Vista, Cape Verde Islands). Afr. J. Ecol. 52: 50-58.

84. Smalley, I., O'Hara-Dhand, K., McLaren, S., Svircev, Z. \& Nugent, H. 2013. Loess and bee-eaters I: ground properties affecting the nesting of European bee-eaters (Merops apiaster L. 1758) in loess deposits. Quatern. Int. 296: 220-

800 226.

85. Smart, M., Azafzaf, H. \& Dlensi, H. 2007. The 'Eurasian' Spoonbill (Platalea leucorodia) in Africa. Ostrich 78: 495-500.

86. Sorace, A. 2001. Value to wildlife of urban-agricultural parks: a case study from 804 805 Linnean Soc. 66: 171-185.

88. Tavares, P.C., Monteiro, L.R., Lopes R.J., Correia Santos, M.M. \& Furness, R.W. 2004. Intraspecific variation of mercury contamination in chicks of black-

87. Staffan, B. \& Hasselquist, D. 1999. Phylogeographic population structure of great reed warblers: an analysis of mtDNA control region sequences. Biol. J. winged stilt (Himantopus himantopus) in coastal wetlands from southwestern Europe. B. Environ. Contam. Toxicol. 72: 437-444.

89. Thomas, F., Deerenberg, C., Lepley, M. \& Hafner, H. 1999. Do breeding site characteristics influence breeding performance of the Purple Heron Ardea purpurea in the Camargue? Rev. Ecol. (Terre Vie) 54: 269-281.

90. Thorup, K. 2004. Reverse migration as a cause of vagrancy. Bird Study 51: 228-238.

91. Tomek, T. \& Guminski, W. 2003. Bird remains from the Mesolithic and Neolithic Site Dudka Masuria NE Poland. Acta Zool. Cracov. 46: 9-19.

92. Tomiałojć, L. 2012. Changes in tree sparrow Passer montanus populations from urban parks. International Studies on Sparrows 36: 4-17. 
93. Velevski, M., Hallmann, B., Grubač, B., Lisičanec, T., Stoynov, E., Lisičanec, E., Avukatov, V. Božič, L. \& Stumberger, B. 2010. Important bird areas in Macedonia: sites of Global and European importance. Acrocephalus 31: 181-282.

94. Venema, P. 1997. Pleisterende Regenwulpen Numenius phaeopus in Drenthe in 1980-95. Drentse vogels 10: 27-36 (in German).

95. Virkkala, R. \& Rajasärkkä, A. 2007. Uneven regional distribution of protected areas in Finland: consequences for boreal forest bird populations. Biol. Conserv. 134: 361-371.

96. Virkkala, R., Luoto, M., Heikkinen, R.K. \& Leikola, N. 2005. Distribution patterns of boreal marshland birds: modelling the relationships to land cover and climate. J. Biogeog. 32: 1957-1970.

97. Walker, D. 2004. Audouin's Gull: new to Britain. British Birds 97: 537-541. status of the Dartford Warbler in the UK and the Channel Islands in 2006. British Birds 102: 230-246.

99. Wotton, S.R., Langston, R.H. \& Gregory, R.D. 2002. The breeding status of the Ring Ouzel Turdus torquatus in the UK in 1999. Bird Study 49: 26-34. 2003. Современное распространение и особенности экологии журавлякрасавки в саратовском Заволжье. Беркут 12: 76-82 (in Russian). 


\section{LEGENDS TO FIGURES}

844 Figure 1. 50x50 km squares for which data were reported for EBBA1 (light grey

845 squares) and for EBBA2 (dark grey dots). EBBA1 data came from 3949 squares and

846 coverage for EBBA2 was 5095 squares (provisional values yet). These values

847 correspond, respectively, to $74 \%$ and $96 \%$ of the total number of squares in the area

848 shown in the map. It is very important to highlight that the completeness of the

849 coverage was very low in EBBA1 in the northern half of Russia and in some parts of

850 Caucasus and the Western Balkans. Data collection for EBBA2 was mainly carried out

851 from 2013 to 2017 in the more than 50 participating countries, including much better

852 coverage in the European parts of Russia and Kazakhstan, the Caucasus countries,

853 the Canary Islands, Cyprus and the whole of Turkey.

854 Figure 2. Number of papers citing EBBA1 that were attributed to each of the analysed 855 main topics.

856 Figure 3. Location of the $1700010 \times 10 \mathrm{~km}$ squares with EBBA2 standardized surveys.

857 In the context of this project, all these squares were surveyed in a standardized

858 manner between one and ten times. Each survey have a complete list of all species

859 recorded in a given time frame at a particular site and on a single day.

860 Figure 4. Pilot map showing the probability of occurrence for the Turtle Dove

861 Streptopelia turtur in all 10×10 km squares in Europe based on EBBA2 spatial

862 distribution modelling (light-dark grey indicates low-high probability of occurrence,

863 respectively). 
864

865 FIGURES

866 Figure 1.

867

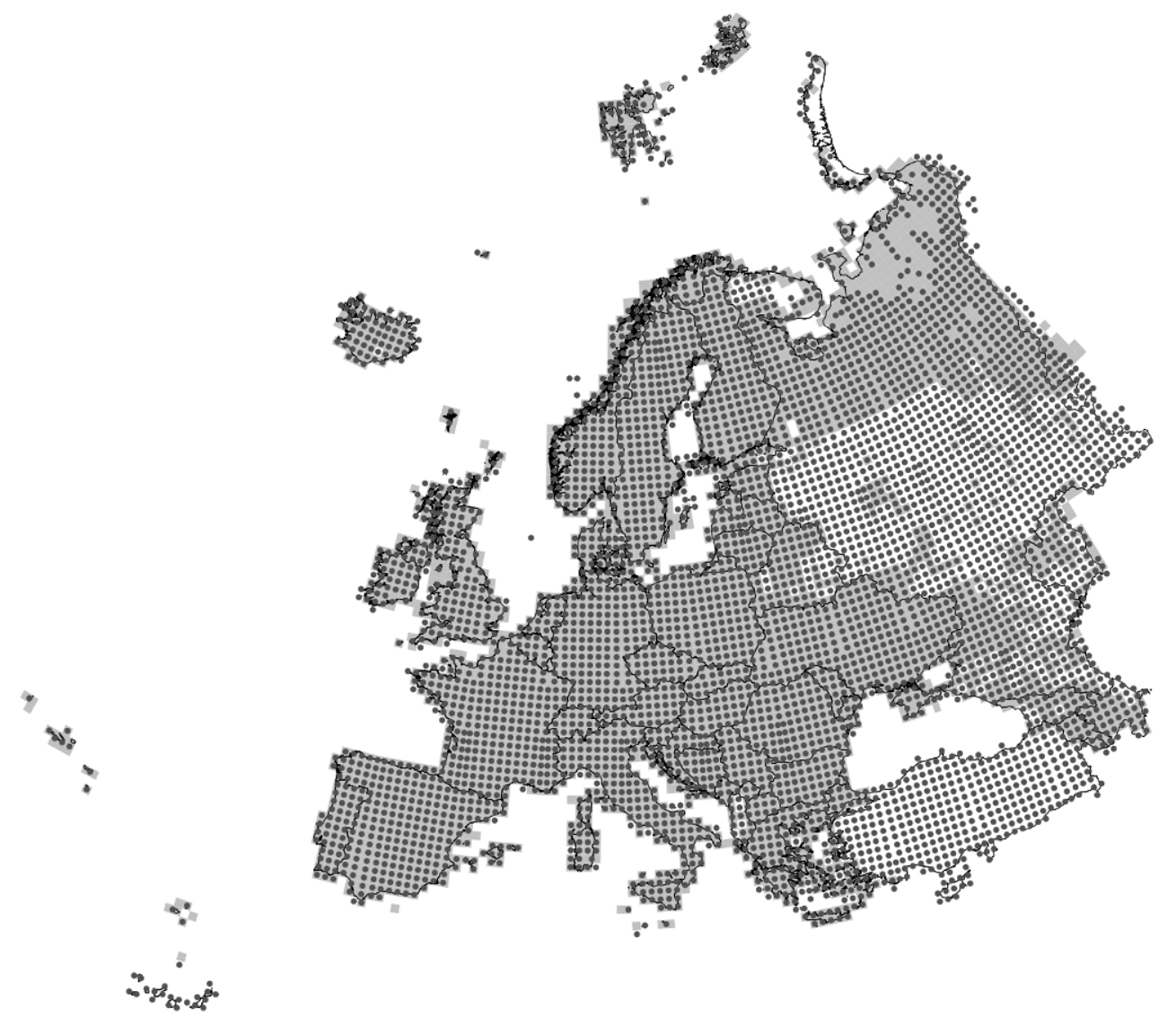

$868 \quad$ Figure 2. 


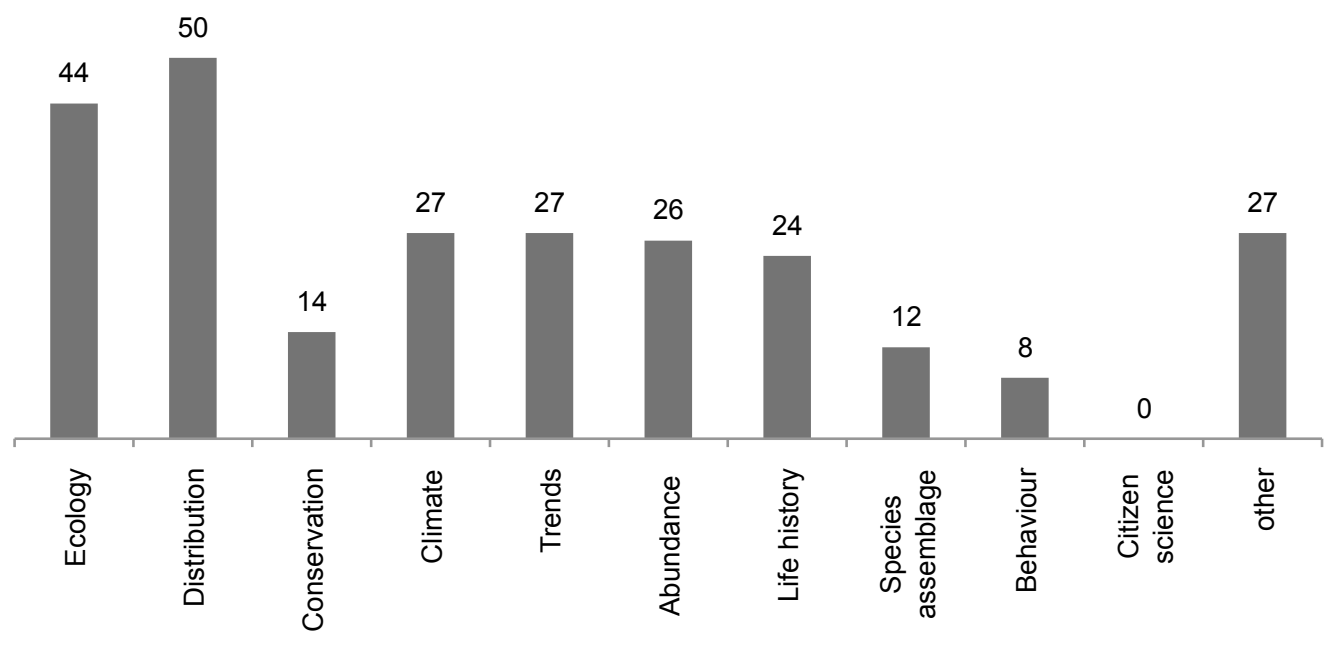

$870 \quad$ Figure 3.

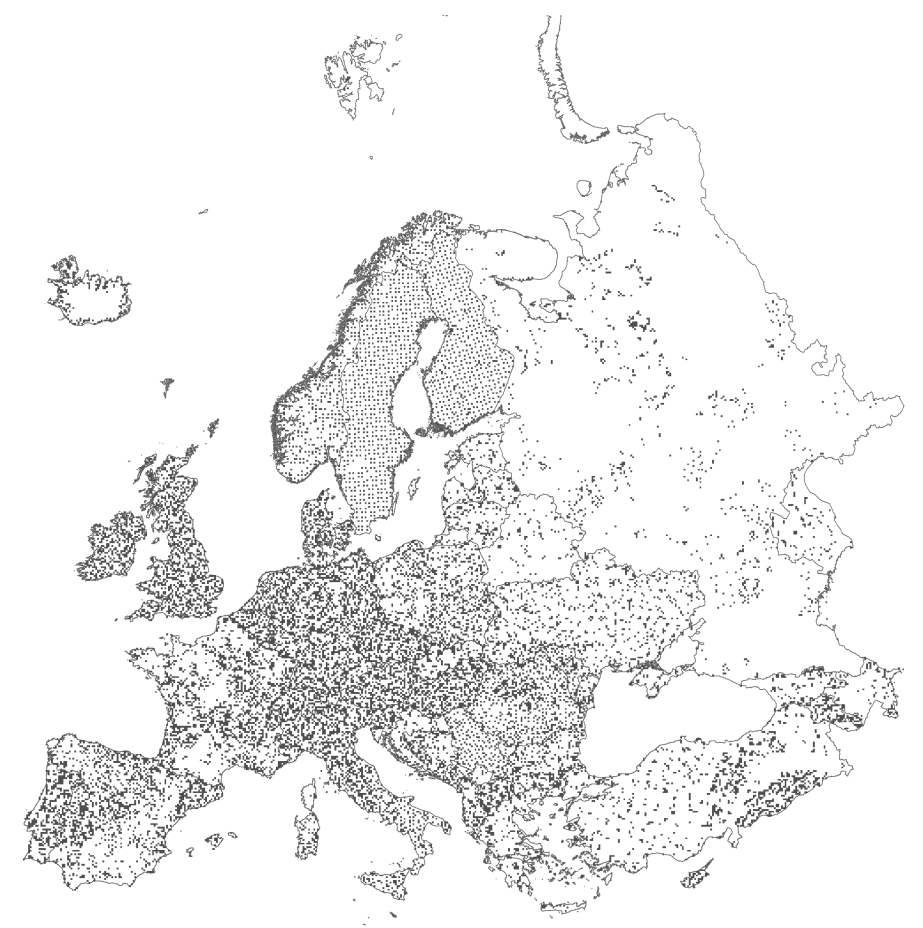

871

$872 \quad$ Figure 4. 


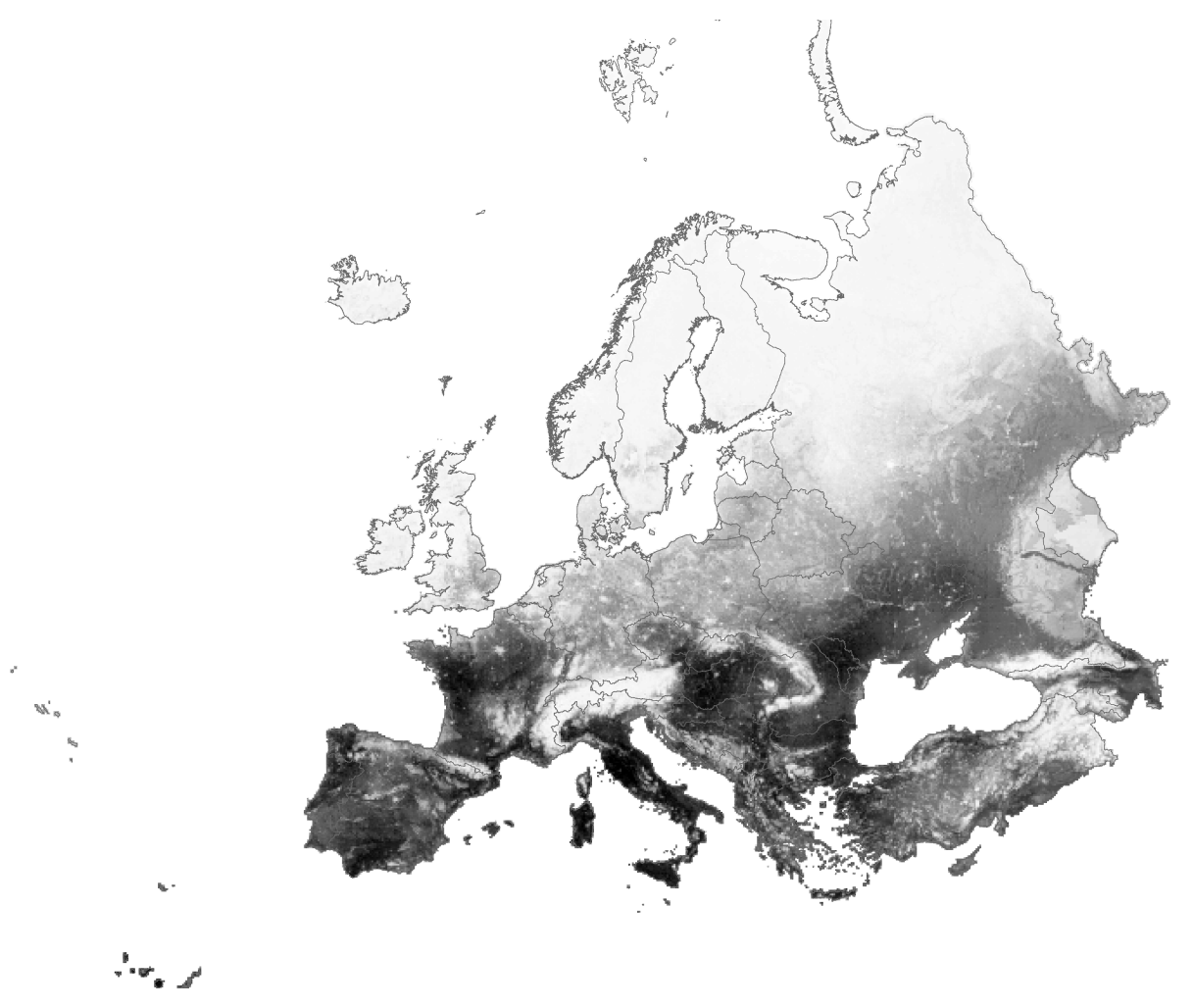

